\author{
Maciej Krzysztof Kluk \\ I Klinika Kardiologii i Elektroterapii Świętokrzyskiego Centrum Kardiologii w Kielcach
}

\section{Dieta w kardiologii prewencyjnej \\ - znaczenie nawyków żywieniowych w prewencji poważnych incydentów wieńcowych u pacjentów z grupy wysokiego ryzyka sercowo-naczyniowego ze stabilną chorobą niedokrwienną serca na podstawie subanalizy badania STABILITY}

Zalecenia dietetyczne mają uznaną pozycję w modyfikacji stylu życia u pacjentów z grupy wysokiego ryzyka sercowo-naczyniowego zarówno w prewencji pierwotnej, jak i wtórnej zdarzeń sercowo-naczyniowych. W odniesieniu do modelu diety śródziemnomorskiej w badaniach obserwacyjnych i randomizowanych udowodniono jej korzystny wpływ na zmniejszenie zarówno częstości poważnych zdarzeń sercowo-naczyniowych, jak i śmiertelności ogólnej. Niekorzystny efekt zdrowotny modelu diety „zachodniej” nie został systematycznie udokumentowany. Model diety śródziemnomorskiej znalazł się w zaleceniach dotyczących prewencji sercowo-naczyniowej zarówno European Society of Cardiology (ESC), jak i towarzystw amerykańskich.

Badanie STABILITY [1] było dużym wieloośrodkowym badaniem klinicznym służącym ocenie skuteczności darapladibu (inhibitora fosfolipazy $A_{2}$ zależnej od lipoprotein) w ograniczeniu występowania poważnych zdarzeń sercowo-naczyniowych (MACE, major adverse cardiovascular events) u pacjentów ze stabilną chorobą niedokrwienną serca, definiowaną jako przebyty zawał serca, przebyta rewaskularyzacja wieńcowa lub wielonaczyniowa choroba wieńcowa. Z kolei MACE zdefiniowano jako zgon z przyczyn sercowo-naczyniowych, zawał serca lub udar mózgu niezakończone zgonem. Do badania włączono 15828 pacjentów obciążonych wysokim ryzykiem sercowo-naczyniowym (starszy wiek, upośledzona funkcja nerek, wywiad palenia tytoniu, albuminuria, choroba naczyń obwodowych, cukrzyca). W badaniu nie wykazano różnic w zakresie częstości MACE między grupami badaną i kontrolną.

W czasie rekrutacji do badania blisko 98\% pacjentów wypełniło formularze oceny stylu życia zawierające szczegółowe dane dotyczące modelu dietetycznego z uwzględnieniem diet śródziemnomorskiej i „zachodniej”. Następnie, na tej podstawie, obliczono wskaźniki diety śródziemnomor- skiej (MDS, Mediterrean diet score) oraz diety „zachodniej” (WDS, Western diet score) zależności od ilościowego spożycia odpowiednich elementów każdej z diet.

Okres obserwacji pacjentów w badaniu wynosił 3,7 roku. Dodatkowymi punktami końcowymi były zgony z powodu zawału serca lub udaru mózgu oraz zgony z przyczyn ogólnych.

Wyższy MDS wiązał się z rzadszym paleniem tytoniu, niższym wskaźnikiem masy ciała, większą aktywnością fizyczną oraz niższymi stężeniami parametrów zapalnych i glukozy na czczo. Nie wykazano istotnych różnic w zakresie stężeń poszczególnych frakcji cholesterolu ani częstości chorób naczyń obwodowych w zależności od MDS. Był on istotnie wyższy w krajach Europy Północnej oraz Azji i Pacyfiku względem regionu śródziemnomorskiego. Nie stwierdzono zależności WDS od obecności nadciśnienia tętniczego, hipercholesterolemii, wskaźnika masy ciała ani parametrów zapalnych. Nie obserwowano związku między WDS a występowaniem MACE. Natomiast MDS wynoszący ponad 12 punktów był związany z istotnie niższym ryzykiem wystąpienia każdego z MACE, co było szczególnie zaznaczone dla punktacji 15 i więcej. Nie wykazano wpływu punktacji MDS i WDS na drugorzędowe punkty końcowe.

Do głównych ograniczeń pracy autorzy zaliczyli obserwacyjny charakter badania, zastosowanie uproszczonego formularza oceny diety oraz stosowanie leków modyfikujących czynniki ryzyka miażdżycy, takich jak statyny (u 97\% pacjentów uczestniczących w badaniu).

W kolejnych wersjach zaleceń towarzystw kardiologicznych warto położyć większy nacisk na podkreślenie roli zwiększenia spożycia produktów odpowiadających diecie śródziemnomorskiej kosztem zmniejszenia spożycia produktów wysoko przetworzonych (dieta „zachodnia”).

\section{Konflikt interesów}

Autor deklaruje brak konfliktu interesów.

\section{Piśmiennictwo}

1. Stewart R.A., Wallentin S., Benatar J. i wsp. Dietary patterns and the risk of major adverse cardiovascular events in a global study of high-risk patients with stable coronary heart disease. Eur. Heart J. 2016 Apr 24. doi:10.1093/eurheartj/ehw125. 